\title{
1 Nordic elementary schoolteachers
}

\author{
Organic intellectuals, agents of a \\ colonising state, emancipatory groups, \\ or all of these?
}

Jesper Eckhardt Larsen

\section{Introduction}

Elementary schoolteachers in Western societies between 1880 and 1920 have provoked ambiguous interpretations in historiography. Was this rapidly growing group a large, grey mass of the humblest servants of the state? Were teachers progressivist and avant-garde fighters on behalf of oppressed groups and minorities in a struggle for power on a national level? Or were they the carriers of primordial cultural values into fights about defining national identity? This chapter will argue that, no matter their role, in disseminating values and ideas to new generations, teachers played a defining part in the development of national self-understandings.

In most or all Western countries, during the first half of the nineteenth century, the village schoolteacher was likely to be a farmer's son. Urban schoolteachers including home teachers were a more mixed group including both male and female teachers of higher and lower social backgrounds. By the turn of the century, however, with industrialisation and rapid urbanisation, the persistent over-recruitment of elementary schoolteachers from rural or small-town backgrounds, as well as the large influx of female teachers, came to be considered increasingly problematic.

The conclusions of an American survey conducted by Lotus Delta Coffman (1875-1938) at the Teachers College, Columbia University (New York) in 1911, show how this recruitment pattern was seen as contributing to the (poor) state of public schooling. Feminisation and predominantly rural recruitment were identified as the most significant problems. Teachers at rural and small-town schools did little voluntarily for self-improvement; there was a want not only of training, but also of 'aptness to teach and of personality' (Coffman, 1911, pp. 82ff).

These perceived recruitment 'problems' are, however, extraordinarily dependent on context. The almost exclusively rural recruitment of elementary schoolteachers in Norway, e.g., has received almost the directly opposite assessment. Lauglo describes the period from 1880 to 1920 as the 'golden age of the teacher-politician' (Lauglo, 1995, p. 267). Teachers with rural or 'popular' origins formed a sort of countercultural movement, with issues such as political rights, nationalism, nynorsk Norwegian language revival, anti-establishment Christianity, and the temperance movement on their agenda.

For the Norwegian national self-understanding, the idea of the so-called 'folk teachers' went through what can be seen as its final test in the cultural and political 
confrontations with the German occupation authorities during the Second World War. Just after the establishment of the Nazi government under Vidkun Quisling (1867-1945) in February 1942, a law was issued, obliging all teachers to join a new, Nazified, teachers' union. In the following weeks, approximately 12,000 out of the country's 14,000 schoolteachers and secondary-school lecturers had sent letters of protest and read statements aloud in their classrooms. This happened alongside a parallel protest by pastors in most churches against a Nazi youth organisation (Hagemann, 1992, p. 201). Quisling was unable to cope with this opposition and, in March 1942, the Reichskommissär, Josef A. H. Terboven (1898-1945) ordered the deportation of 1,000 schoolteachers to work on fortifications in northern Norway (ibid., p. 205). It was arguably in the defence of Norway as a survival unit (to use a term discussed in more detail later in this chapter) that Norwegian teachers got their final stamp as the co-definers and defenders of the nation's political and cultural existence.

American historiography shows the special emancipatory significance that elementary schoolteachers, as an occupation group, have had in the United States. Here, teachers as progressivist avant-garde fighters on behalf of oppressed groups and minorities struggling for power on a national level have played a central role for assertive and struggling groups. Indeed, African Americans have been better represented among teachers than in any other professional group. In this regard, the teaching profession has been an important avenue for the development of an educated cadre of leaders in the African American community (Rury, 1989, p. 10).

What are the historical circumstances and characteristics of the national paths in this period that have determined the differing national importance of schoolteachers? In our own time of identity politics, it is instructive to review how the circumstances of earlier times led to frontline leaders emerging from among schoolteachers who, I argue, gained legitimacy from their social, geographical, cultural, and racial origins, sometimes from their gender, and sometimes from their families' social and occupational backgrounds.

\section{Methods and data}

This chapter combines descriptive statistical analysis of quantitative data on teacher recruitment patterns (sociocultural background, rural/urban origin, gender, etc.), and information on the rationale behind the geographical placement of pre-service teacher educational institutions, with qualitative and historical analysis. By mixing methods, it becomes possible to assess the quantitative data on 'urban' versus 'rural' and 'elite' versus 'folk' recruitment, and the male/female recruitment ratios in the Nordic region during 1880-1920, before moving to an assessment of the broader cultural and political significance of these recruitment patterns in an international comparative perspective.

Statistical overviews of individual pre-service teacher education institutions from the period itself, or immediately after, often only give the occupational details of the fathers of student teachers. From this material alone, it is difficult accurately to categorise recruitment as being rural or urban, or to categorise it in relation to 
social status or class affiliation. Statistical material and historiography on recruitment since the 1930s or so has, by contrast, categorised these recruitment patterns primarily according to status and class, making data and secondary interpretations less comparable over time. The recruitment data can, however, serve as indications of overall national patterns. Especially relevant in this data are the percentages of student teachers from farming families (indicating the 'common' or 'folk' origin of teachers), the level of self-recruitment in the teaching profession, i.e., how many come from teacher families (indicating the level of professionalisation), and the gender ratio.

\section{Structure of the chapter}

The next section introduces the theoretical framework of the chapter, with a tentative placement of the eight national cases (see Figure 1.1). This framework structures the following parts of the chapter. The first set of national cases, of 'organic teachers in culturally defensive countries' - Ireland, Denmark, and Norway - will then be analysed, followed by an analysis of 'colonising teachers in culturally expansive countries' - Germany, the United States, and Sweden. The next section discusses 'colonising teachers in culturally defensive countries' - Finland and Iceland. This is followed by reflections on how these cases reflect co-occurrences, rather than causal relationships, between nation-state and teacher types. Finally, the conclusion opens up the discussion to broader comparative interpretations of the impact of these teacher types.

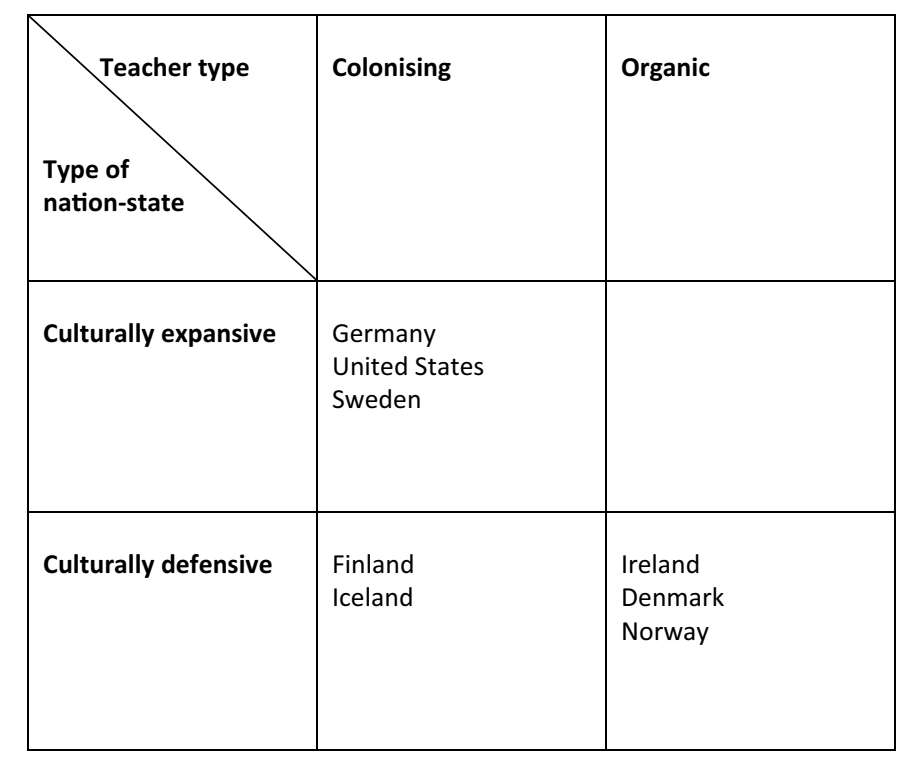

Figure 1.1 Framework of teacher types. 


\section{Aims, questions, and conceptual framework}

One aim of this volume is to investigate the particularities of Nordic teacher cultures, i.e., to identify and describe the characteristics of teachers collectively, by looking at the groups of individuals in the teaching profession in the various Nordic countries. In this chapter, I also compare Nordic teacher cultures with those of Ireland, Germany, and the United States. This demands some reflections on the historical causes of these characteristics which, in turn, requires a theoretical framework of such consistency that it allows for cross-regional comparison. Simply put: what exactly are we comparing when we compare 'teacher cultures' or nationally dominant 'teacher types'? And, secondly, can we operationalise a theory that explains similarities and differences across many cases? In this chapter, I attempt an assessment of the cultural significance of recruitment into and placement of initial teacher education institutions ca. 1880-1920. The research questions of this chapter are:

i Where did Nordic student teachers come from, socially and geographically, compared with those in Ireland, Germany, and the United States?

ii What significance is ascribed to these patterns of recruitment by actors and contemporary observers as well as by later historiography?

iii Where were pre-service teacher education institutions placed and why?

iv What role, if any, did concepts of 'folk' and similar notions play in discussions about teacher education, its recruitment, and location?

$\mathrm{v}$ How are the differing dominant teacher types connected to national selfunderstandings including national cultural strategies?

I will place teacher groups into a framework of nation-states which are, as discussed below, seen as survival units. Teachers have often, at least in times where national sentiments and loyalties are paramount, played a role as the guardians of nationhood. Teachers have, especially in times of relative secularisation, been responsible for reproducing in the next generation a certain minimum of loyalty towards the nation-state. The period this chapter is concerned with, from around 1880 until the 1920s, saw unprecedented public nationalism, the relative secularisation of civil society, and in many cases, active efforts to build or consolidate the nation. I introduce here, a simple matrix of ideal types as a starting point for an explanatory framework.

The connections suggested in Figure 1.1, e.g., in the top-left quadrant between a culturally expansive strategy of a nation-state, and a colonising teacher type, intuitively seem to be confirmed by many historical cases. In the case of South America, which is not developed further here, Caruso has shown that teachers during the nineteenth century actively spread language, ideas, and values from the centre towards the periphery in a colonising way, almost as a continuation of the colonial strategies of European powers in the previous century (Caruso, 2012). However, the matrix also shows less intuitive co-occurrences. As will be discussed below, Finland and, to some extent, Iceland are countries with culturally defensive strategies, e.g., in the field of protecting their national languages in the light of foreign 
dominance but have a colonising teacher type. The only 'simple' indication is that we exclusively find the organic teacher type in nations with a culturally defensive strategy (i.e., in the bottom-right quadrant).

The correspondence between colonising/expansive, as well as organic/defensive was a working hypothesis. But with the two outliers we identified, these cooccurrences must be questioned and investigated for each case in turn. Thus, the categories in Figure 1.1 primarily serve as heuristic tools to show differing cooccurrences rather than to suggest any deterministic or linear causation. These can clarify what to look for in individual cases and thus serve as a tertium comparationis in the overall comparative analysis.

The two teacher types in Figure 1.1 refer mainly to teachers' roles on a societal or nation-state level. The colonising teacher type has affinity to the centre in relation to the periphery. The centre sends out its educators to promote loyalties to the nation-state in all its geographical regions, as Göttlicher finds in Austria, Schulte in China, and, as mentioned above, Caruso in South America (Caruso, 2012; Göttlicher, 2019; Schulte, 2014). These efforts are apparent not only in rural areas, but also in urban areas, in the latter between socially distinct areas. The colonising teacher type is often educated in larger, central cities and the connection with his or her sociocultural background (if not urban middle class) is not deemed anything other than a possible obstacle to becoming a tool of the civilising aspirations of the ruling group at the centre. If a student teacher is from rural or lower-class origins, forgetting previous values, habitual behaviours, group affiliations, and even traces of a dialect or sociolect, is part of becoming a teacher.

The organic teacher type is the opposite: this type is defined as bringing previous values, habitual behaviours, group affiliations, and dialects/sociolects into play when incarnating the role of a teacher. This type, conceptually inspired by Antonio Gramsci, has also been described in the Irish case (Johnson, 1992). This teacher type is often educated in smaller towns or rural settings, where there is a conscious effort to preserve the primordial sociocultural heritage of student teachers. The affinity of the student teacher with place and culture is instrumental in bringing about a culturalisation of new generations into a cultural loyalty towards the nation-state.

Though inspired by his work, this application has no direct references to Gramsci's own categorisations, as he most often places schoolteachers in the category of traditional intellectuals. He separates intellectuals not only into the traditional and organic types, but also into the rural and urban types according to the place where they worked. The rural type, he declares, is for the most part 'traditional' - a group that includes the countryside 'priest, lawyer, notary, teacher, doctor, etc.' (Gramsci and Hoare, 1971, p. 14). Additionally, Gramsci does not believe that groups of peasants would develop their own organic intellectuals (ibid., p. 6). Rather, when intellectuals, like priests, were recruited from peasant backgrounds, they would leave their original loyalties behind (as with the colonising teacher type, above). It can however be argued that Gramsci is mostly referring to Southern European contexts, and rural teachers with farming backgrounds in Ireland, Denmark, and Norway do exhibit traits that arguably resemble those of organic intellectuals. Thus, in this northern context, the organic teacher type is seen as 
connected to farmers as a group, in opposition to the way that Gramsci uses the term, where organic intellectuals were almost exclusively from urban workingclass backgrounds.

It is important to stress that rural recruitment does not invariably result in an organic teacher type. The emergence of the type depends on the character of preservice teacher education, which also raises the question of the location of preservice teacher education institutions. Göttlicher, in writing about Austrian country schools, explains that although some recruitment for teacher education institutions was from the countryside, the location of the teacher training institutions in the larger cities turned teacher training into a form of 'class travel', i.e., a change in social standing and cultural habitus of the individual student teacher (Göttlicher, 2019). The 'culture' of rural recruits was overruled in the process of obtaining a centralised urban pre-service teacher education. Each of the national cases therefore demands a closer analysis of the character and geographical location of teacher education institutions.

\section{Cultural strategies of nation-states}

For Norbert Elias, the nation-state is a survival unit within an environment of other, potentially hostile, states. The consequence is that the nation-state must organise itself to procure at least a sufficient defence. This defence should be regarded in the broadest possible terms, ranging from soldiers and military weapons to culture, ideology, and social organisation (Elias, 1978; Reeh, 2016). In this perspective, the education of a population can be seen as a means by which the state secures a certain cultural and political cohesion in its more-or-less open strife with other states for survival. This does not just become relevant during wars, but also in day-to-day consolidations of national self-understandings, as I discuss below in the case of Nordic 'folk' ideology. Reeh argues on the basis of Norbert Elias and others that all nation-states must primarily be seen as survival units, and connects this to, in turn, religion, education, and nationalism. In his analysis, long before the overt discourse of 'competition states', religion, cultural nationalism, and mass education have served the object of mobilising the population for state survival and wars to come (Reeh, 2016). On the basis of this ubiquitous need for a cultural survival strategy, I shall distinguish between two ideal types: a culturally expansive strategy and a culturally defensive one.

A nation-state with a culturally expansive strategy has sufficient power and resources to hold its territory, as well as the soft power to dominate other neighbouring regions culturally. The United States during most of the twentieth century demonstrated this cultural strategy. A prime example is the Harvard Report from 1945, titled General Education in a Free Society. The concept of freedom in this report is to be understood as a contrast to both Nazism and Socialism, and it emphasises a self-understanding marked by the United States' new global role as the defender of freedom and inheritor of the Western democratic cultural heritage. In this understanding, the role of education and learning is to extend the classical notion of liberal education, i.e., the culture of the free, noble, and high classes, to all citizens (Buck et al., 1945). 
A nation-state with a culturally defensive strategy has, on the contrary, issues with upholding its territory and cultural independence. It lacks both the hard power to back its territorial claims and the soft power to expand its cultural values to other surrounding nations. This can be seen in the case of Denmark, which was threatened by state bankruptcy in 1813, the loss of Norway in 1814, and wars with Germany in 1848-1850 and 1864. Already in 1816, the Danish pioneer of a 'folk ideology' N. F. S. Grundtvig (1783-1872) called for building a spiritual wall against European influence and likened it to the fortress raised against the German invasions in the early middle ages (Et andeligt Danne-Virke). This, he wrote, would serve to protect the Danish culture and language (Grundtvig, 2016 [1816]).

\section{Nordic folk ideology}

The Nordic countries have been described as being discursively dominated by a continuity of positive political connotations of the 'folk' concept since the late nineteenth century (Trägårdh, 1990). This concept can be translated as 'common people', as well as 'a nation'. The historical emergence of a Nordic model of education builds on specific political alliances and discourses that differ from both German and American trajectories. A decisive difference is noticeable in how nationalism and folk ideology influenced educational reform processes in the Nordic countries during the late nineteenth and well into the twentieth century. From the comparative work on the divergent paths of the 'Volk/folk' discourses in Germany and Scandinavia, it is apparent that the concept of a 'folk' has left an important mark on Nordic liberal and social democratic party politics and, by extension, on Nordic educational self-understanding (Lauglo, 1995; Trägårdh, 1990). Briefly summarised, an alliance between liberal farmers and reformist social democratic workers formed in the early twentieth century. The Nordic conception of 'folk' was thus coloured by liberalism in combination with democratic reformist socialism and was distinguished by class compromise. Thereby it departed from the völkisch ideologies instrumentalised from the 1920s onwards in Germany (Ibid.).

Struggling with the concepts of 'folk' and 'folk teachers', Lauglo, in his contribution on teachers as community leaders in Norway compared to other Western countries, chooses to call the specific Nordic path a variant of populism as a political and cultural force.

In negative terms, populism - often taking the form of protest movements in the name of the cultural, economic, and political values and beliefs of ordinary people - is a reaction against elites. In positive terms populism represents a direct and local democracy that seeks to empower ordinary people.

(Lauglo, 1995, p. 256)

Following Lauglo, it is clear that belonging to a folk is not (only) a social distinction, but a cultural one. Populism differs from socialism in that it doesn't delimit its loyalties through social class distinction, but rather through cultural or ethnic distinctions. In the above framework, however, it is not totally self-evident that the 
cases which promote organic teachers are also more concerned with strengthening democracy or directly empowering ordinary people. One may problematise the frequent claim that the Nordic countries are more democratic, or even more directly democratic, because of their folk ideology. It has also been argued that statism is very strong in the Nordic countries (e.g., Wiborg, 2009).

\section{Ireland, Denmark, and Norway: organic teachers in culturally defensive nations}

In this section, I argue that elementary schoolteachers played similar roles in Ireland, Denmark, and Norway. The Irish case is an obvious example of a conscious policy of 'creating' schoolteachers who were expected to incarnate and adhere to a narrower definition of a primordial national culture in the midst of a conscious nation-building process. This both influenced the deliberate geographical placement of teacher education institutions and their intentionally rural recruitment. The Irish case is not fully developed here but is used as a parallel case to two westNordic countries, Norway and Denmark.

\section{Ireland: the intentional political construction of the teacher as an organic nation-builder}

Johnson describes in detail how the deliberate recruitment of schoolteachers from the Gaeltacht areas in the west of Ireland, who had Gaelic as their mother tongue, gained strategic importance in the first part of the twentieth century, as the movement towards Irish independence gathered pace. The Irish language was to emerge as the foundation of primary education and the west of Ireland, where there was the greatest concentration of Irish speakers, was to become 'the synecdoche of Irish identity'. This region, Johnson explains, was to be the beneficiary of a cultural policy that would recruit teachers as 'organic intellectuals' to implement the state's language revivalist policies (Johnson, 1992, p. 175).

In Dublin in 1921, a National Programme Conference was held with representatives of a variety of educational interests. The conference recommendations were immediately implemented by the Irish parliament in late 1922 but a lack of competent teachers to carry out the linguistic part of the curriculum quickly posed problems. The government, therefore, had to seek a way whereby competent teachers of Irish might be secured for the future. In 1926, it was decided to establish a preparatory college system in secondary education to recruit teachers for the training colleges. In order to imbue students with a heightened consciousness of being Irish speakers, it was asserted that with the exception of two colleges to be established in Dublin, they should be situated in the Gaeltacht, 'where the language and tradition of Gaelic Ireland are still a living force' (Department of Education, 1927; quoted in Johnson, 1992, p. 178). Seven colleges were established, three for Catholic boys, three for Catholic girls, and one Protestant coeducational college. Johnson views this as an attempt to deliberately mediate between the state and civil society through the instrumentalisation of schoolteachers acting as organic intellectuals. 


\section{Denmark: a country divided}

The role of schoolteachers in local rural communities in Denmark during 18801920 has been widely debated, and many scholars have pointed to the ambiguousness of this group. On the one hand, the developments in teacher education, combined with the growing prominence of commercial farmers as a group, gave rise to teachers as the organic intellectuals of these farmers, e.g., representing them politically on a national level. On the other hand, this was also a time of decline in the status of teachers from a socioeconomic viewpoint.

In Chapter 7, Cucco and Larsen argue that a 'Danish schism' can be said to characterise the national self-understanding. The educated urban academic groups stood against countercultural movements defined by Grundtvigian folk ideology. To a very large degree, teachers were active on the folk side of the schism.

Until the middle of the nineteenth century, teacher education was a state monopoly in Denmark, after which pressure from the Farmers' Friends Party (Bondevennerne) and Grundtvigian circles led to its liberalisation in 1857 and again in 1867. This created a window of opportunity for groups in civil society to establish their own alternative teacher education institutions, e.g., Grundtvigian groups, Inner Mission groups with countercultural agendas, and groups of women with an emancipatory agenda. Many of these institutions remained viable well into the twentieth century and became more and more integrated into Danish statehood. The Grundtvigian influence diffused quite significantly into state institutions. Hjermitslev concludes that by 1920, Grundtvigian ideas were mainstream in most private and state teacher seminaries in Denmark (Hjermitslev, 2020). These ideas included both low-church Christianity and nationalistic ideas of primordial Danishness. According to the jubilee book of the Grundtvigian Jelling seminary in 1918, any local school board which chose to employ a teacher educated at this seminary could rest assured that it would get a 'Christian man, a Danish man' (cited in Grinder-Hansen, 2013, p. 125).

Danish historiography of teacher recruitment paints an ambivalent picture of the rural Danish schoolteacher from the 1880s until the turn of the century. On the one hand, it is clear that teachers' social position generally deteriorated. Economically and agriculturally, they were placed alongside lower-class farmers (husmond) - and, like them, were dependent on the wealthier commercial farmers. However, in these years, many teachers came to play a prominent role in society at both local and national levels. If the teacher saw an opportunity in the local community and had the ability, will, and initiative, then he and the school might become a sort of centre of gravity for the community. This opportunity could be the establishment of evening schools, lecture associations, and the construction of community assembly halls - but teachers were also often among the initiators of the cooperative movement (Hansen, 1977, p. 45).

Grinder-Hansen's description of the teacher in this period is also ambivalent. He defines the folk teacher as a special teacher type (Grinder-Hansen, 2013, p. 119). In this context, it is obvious that the concept of folk teacher must be perceived in parallel with Gramsci's concept of a teacher who also functions as an organic intellectual. The Danish village teacher could, by virtue of his social 


\section{Jesper Eckhardt Larsen}

background in the farming population, his low social status, and being paid in kind, take a position as primus inter pares - the foremost farmer among farmers (see Chapter 3).

In spite of the large number of women who passed the teacher exam around the turn of the century, female teachers played a minor role in the countryside prior to 1900. Women held around 15\% of teaching positions outside Copenhagen in 1895 including preschool teachers (Tabellariske Meddelelser vedrørede Borger- og Almueskolevesenet udenfor Kjøbenhavn for Aaret 1895, 1899). We do not have many sources on their social backgrounds, but one source investigates 720 women who had passed the teaching exam and held positions as teachers. ${ }^{1}$ Of these, $62 \%$ were employed in the Copenhagen area, 24\% in larger provincial towns, and only 14\% in the countryside. Around half were the daughters of officials, businessmen, or craftsmen in Copenhagen, a third were daughters of officers or craftsmen in provincial cities and smaller businessmen in Copenhagen, and only 13\% were daughters of farmers and village craftsmen (Hansen, 1977, pp. 36ff). This picture changed somewhat when political initiatives were taken to educate female preschool teachers for rural areas. From 1894 onwards, between 25 and 100 female preschool teachers were educated each year in special seminaries (Larsen, 2005). However, these teachers never gained the same quantitative significance in Denmark as they did in Sweden, as will be described below.

Data from 1859 and again from 1869 to 1896 show a high degree of selfrecruitment: around a quarter of all student teachers belonged to teacher families. However, during this period, the most prominent group comprised children of commercial farmers at $27 \%$, dropping to $24 \%$ in $1897-1925$. The proportion of teachers recruited from families of small farmers decreased, from a quarter of all teachers in 1869-1896, to just above $20 \%$ around the turn of the century, to $10 \%$ in 1920 (Hansen, 1977, p. 130). Female recruitment increased considerably after the turn of the century, as men and women were increasingly educated at the same institutions. Women constituted $38 \%$ of candidates who passed the teacher exam in the period 1897-1925. Female recruitment became broader but remained comparatively more urban and bourgeois than the male, a tendency that held until after the Second World War (ibid., p. 174).

In Denmark, therefore, the period 1880-1920 was dominated by rural recruitment combined with substantial self-recruitment and an increase in female recruitment. The high degree of self-recruitment has been seen as an indication that a well-established profession was already in place in the first half of the nineteenth century. This, as will be seen, was also the case in Germany. The large proportion of sons of commercial farmers is interesting in the light of the research question as to whether teachers were from the 'people' - and here we see persistent recruitment from the economically assertive commercial farmer group, whereas recruitment from small farmers decreased after the turn of the century. With well over half of all teachers coming from rural backgrounds up to the 1920 s, we see a fairly pronounced local and rural recruitment pattern. 'The man from the plough' became the teacher, right up until after the Second World War.

This recruitment pattern, and the countercultural dominance of pre-service teacher education institutions which were most often placed in rural settings, 
shows that the thesis about teachers as the organic intellectuals of the group of commercial farmers is defendable in the Danish case. In Denmark, unlike in Ireland, this teacher type emerged more slowly, and with a less overt political intention of creating teachers as organic intellectuals. However, it can be argued that Grundtvigian groups pushed for the development of this teacher type also on a national political level.

\section{Norway: celebrated folk teachers}

The narrative of the folk teacher is far more widespread in Norwegian historiography. Certainly, folk teachers seem impressive - at least from a distance. Slagstad, writing quite recently, is highly enthusiastic (Slagstad, 1998, 2008); Dokka, from an earlier generation, is cooler (Dokka, 1967); and contemporary nineteenth-century Norwegian views were quite derogative. The liberal press of the time was especially hard in its verdicts on these rural seminarists, calling them 'schoolmaster-caricatures', 'half-educated vagrants', 'trained apes', 'marionettes, un-folkish halfwits, unnational idiots', 'the most screwy caricatures', or 'seminary-cut school-master types' (Dokka, 1967, p. 234). Nearer to the present, Lauglo, a Norwegian comparativist who was active in London, seems to seek neutral ground, but still tends to the celebratory when it comes to his country's folk teachers (Lauglo, 1982, 1995). This brief overview makes it evident that historiography contributes strongly to the construction and consolidation of a national cultural self-understanding, and that the countercultural movements, often including teachers as dominant figures in the late nineteenth century, have 'won' a very important status in Norway.

The window of opportunity that opened in Denmark, in which groups in civil society could create their own alternative teacher training institutions, also opened in the Norwegian case from about 1890 to 1920 (see also Chapter 2). This resulted in the emergence of 'folk' institutions like the private seminary established in 1895 in Volda, Western Norway, which became a famous hub of the so-called 'WestNorwegian teachers' (Vestlandslareren) described as ardent supporters of the nynorsk linguistic and cultural movement and as 'nation-builders of the periphery' (Høydal, 1995).Adding to this, most state seminaries established since 1826 were also located in the countryside.

The Norwegian recruitment pattern is the most rurally dominated of all the cases described in this chapter. In Norway, during 1875-1876, 98\% of students at seminaries and teacher schools had rural backgrounds (bygdebakgrunn). Only $5 \%$ were sons of teachers, pointing to a low level of self-recruitment. In 18671881, the Hamar seminary had 436 student teachers, of whom only three were from urban backgrounds. In 1877-1882, the Kristiansand seminary (formerly at Holt) had 230 student teachers, of whom 24 were from urban backgrounds. The same pattern occurred in the private teacher schools (Dokka, 1967, p. 234; Hagemann, 1992, p. 39).

This resulted in a migration of teachers from the rural, often western parts of Norway, to the south, north, and east. Not only in the cities, but also in the smaller villages of eastern Norway, it was commonplace for virtually all teachers to come from outside. Generally, teachers came from the periphery and from lower social 
strata. In other words, teachers were, very often, more or less strangers to the milieu in which they worked (Dokka, 1967, p. 235).

In 1860, it became possible for women to become teachers in rural areas and, from 1869 onwards, also in the towns. This is late in comparison with other Nordic countries. From 1875 to 1895 , the percentage of female teachers in rural schools increased from $2 \%$ to $21 \%$. In Christiania (later Oslo), the feminisation of teaching occurred even more strongly as the percentage of female teachers rose from $29 \%$ to $62 \%$ between 1870 and 1890 . This led to the establishment of a union for female teachers in 1912, which became central to promoting not only their equal status to male teachers, but also pedagogical reform and women's rights on a national level (Hagemann, 1992). Female teachers were more likely to come from urban business and academic families than their male counterparts. This tendency held as late as 1948-1949, but at this point, there was also substantial recruitment of female teachers from rural backgrounds (ca. 42\%) (Strømnes, 2006, p. 122).

Teachers were, as a social group, over-represented in the Norwegian parliament in the late nineteenth century. This over-representation has been interpreted as a product of a social phenomenon. Bull argues, in tune with Gramsci, that every broad, popular movement needs its intellectuals, i.e., people who are more or less professionally trained to think systematically, and to shape their thoughts in speech and writing. In European bourgeois liberalism, lawyers largely filled this role, while in Norway it was filled by teachers (Bull, 1967; ref. to by Jordheim, 1988, p. 68). Slagstad characterises Norwegian teachers as a 'new popular elite group' and explains how these groups succeeded in gaining national hegemony: the existing urban elite disintegrated, and a reforming wing within this elite entered into a coalition with folk teachers (Slagstad, 2008).

The rural placement and countercultural tendencies of many pre-service teacher seminaries, and the overwhelmingly rural dominance in recruitment during most of the 1880-1920 period contributed to the development of an organic teacher type in Norway. The female influx into the profession was more urban, but many rural women also became teachers. Again, it must be stressed that the organic teacher role emerged slowly and was not a result of direct political intervention as in the Irish case. The organic teachers of Norway nevertheless grew to having a significant influence on the national political level and to co-define Norwegian cultural self-understanding.

\section{Germany, the United States, and Sweden: colonising teachers in culturally expansive nations}

It may seem odd to place these quite differing countries in the same category, of nation-states with a culturally expansive strategy. Obviously, all three have been militarily expansive in their turn. In the period dealt with in this chapter, Sweden was still a dominant power - Norway was under the Swedish throne until 1905 and arguably had a culturally dominant position and self-understanding in spite of its comparatively small population. Germany and the United States were both rising world powers at the start of the twentieth century. But, in the case of teachers, their decisive characteristic in the three countries may be self-confidence as the 
emissaries of culturally dominant nations. In all three cases, teachers were carriers of a superior culture to all areas of the country, with a mission to both educate children and sometimes even their parents, and to heighten their culture.

\section{Germany: a first mover with an ambiguous cultural strategy}

In his analysis of the civilisation process, Norbert Elias describes the German national identity as formed in a defensive bourgeois showdown with the French aristocratic culture that had dominated the German states during the seventeenth and eighteenth centuries. This became a German ideology of culture (Kultur) set against French civilisation. The German urban bourgeoisie formed the centre of German national self-understanding, characterised by a lateral relationship between the educated middle classes in German cities, the Bildungsbürgertum (Elias, 1995, pp. 7ff). In spite of this self-understanding, which might otherwise place it in the category of nation-states with a defensive cultural strategy, Germany also shows traits of an expansive cultural strategy. The decisive indicator here is that of the urban bourgeois dominance in national cultural self-understanding.

German states, with Prussia as their leading example, introduced pre-service teacher education already during the eighteenth century. In 1806, there were 11 state-driven seminaries in Prussia (Bölling, 1983). This push for state-driven professionalisation spread to other German states as well as to Denmark and, in turn, Norway. In this way, Prussia was a first mover in the professionalisation of teachers. Germany has thereby been a case of its own kind and radiated influence to all its neighbouring countries as well as the United States (Albisetti, 1993, p. 260).

In German historiography, elementary school teaching has been seen as a stepping stone or platform for upward social mobility into the dominant group of the educated middle class, not least because of the many examples of successful advancement over two generations (Bölling, 1983, p. 76). In the German context, the narrative of the growth of the bourgeoisie (Bürgertum) where teachers' sons and daughters were a central group from which new members of the educated middle class (Bildungsbürger) were recruited has, however, been contested by other studies that point to a more general recruitment of petite bourgeois into this group (Bölling, 1978, p. 22). There appears to be a strong urge among elementary schoolteachers to emulate high-school teachers. Firstly, a move from rural to urban school positions is evident, not least motivated by better working conditions for the individual teacher. Secondly, accusations of 'half-learning' (Halbbildung) made elementary schoolteachers intensively seek further education. The largest German teachers' unions established numerous libraries and arranged courses for teachers. Already in 1848 , and again around the turn of the century, there were demands from the teacher unions to move teacher education from seminaries into the universities. This was, according to Bölling, not only to enhance the status of the profession, but also to seek the higher degree of 'spiritual freedom' that was prevalent at the universities, compared to the strict patronage and discipline that dominated German pre-service teacher seminaries. Since the scientific training to which they aspired was the hallmark of the grammar schoolteacher, these became models of collective self-identification for elementary schoolteachers (Bölling, 1978, p. 18). 
A general picture of the German development is hard to develop, not least because of the large differences between states as well as the particularities of individual seminaries and their geographical locations. A 1928 study of all male student teachers at Bavarian seminaries in 1872-1920 shows that almost a third were the sons of teachers. During this period, the recruitment of farmers' sons fell from $20 \%$ to $10 \%$. The recruitment of the sons of professionals (doctors, priests, etc.) and state officials increased from 10\% to 26\% (Bölling, 1978, p. 21). These numbers mirror those in Prussia which, in many respects, was recognised as the schooling model for all German states during the nineteenth century. In four small-town Prussian seminaries in Brandenburg, between 1880 and 1925, 16\% of student teachers were farmers' sons, $16 \%$ were teachers' sons, $44 \%$ were sons of merchants and workers, and $24 \%$ came from the families of higher and lower officials and other whitecollar workers (Bölling, 1983, p. 78). ${ }^{2}$

In some German states, it was possible for women to receive teacher education already from the beginning of the nineteenth century. However, all-male seminaries dominated, numbering 111, compared to five all-female seminaries in 1876 (Enzelberger, 2001, p. 102). This late feminisation has been connected to early professionalisation. In 1913, only around $21 \%$ of the teachers in Germany were female (Albisetti, 1993, p. 255). In the larger city of Leipzig, female teachers were of much higher social backgrounds than their male counterparts: in 1903,34\% were the daughters of academics or military officers, and 37\% of businessmen (Bölling, 1983, p. 80).

The recruitment numbers changed markedly with the introduction of the Pädagogische Akademien, which provided academised teacher education, in 1925. An overview of recruitment in 1929-1930 shows only 6\% of male students were farmers' sons. The self-recruitment of both genders from teachers' families stood at $21-22 \%$. Recruitment from higher and lower officials, and from white-collar workers' families was high for both genders (43\% of the male group and $30 \%$ of the female group), while a much larger part of the female student teachers came from academic family backgrounds (27\%) compared to their male counterparts (only 3\%). Thus, a more socially exclusive tendency in teacher recruitment accompanied academisation, may be explained by the higher expenses it entailed for families (Ibid., p. 77f). ${ }^{3}$

The high level of self-recruitment characterising the German case has been interpreted as a result of early professionalisation (Albisetti, 1993). In the new century, rural recruitment was still seen as a problematic issue in the German case (Fischer, 1916). But the tendency of these rural schoolteachers was to emulate their secondary school colleagues, not to form a countercultural movement. Comparatively, early academisation contributed to more urban and middle-class recruitment. The resulting pattern was that of a colonising teacher type.

\section{The American teaching profession: grey masses or co-definers of a progressive nation?}

In the United States, in 1850 and 1900, rural backgrounds were most common even among urban teachers (Rury, 1989, p. 27). A 1910 study gives a more detailed breakdown of the rural/urban ratio in recruitment. A disproportionately high 
number of teachers came from farming families: in the male group, $70 \%$, and in the female group, $45 \%$. In comparison, the census of 1900 shows only $40 \%$ of all men and $18 \%$ of all women were in agricultural occupations, showing that the share of teachers with an agricultural background was far larger than expected. The second-largest group was the sons and daughters of artisans, who contributed $8 \%$ of male teachers and $16 \%$ of female teachers. This was followed by the children of businessmen who comprised $15 \%$ of the female group and $6 \%$ of the male group (Coffman, 1911, p. 73).

In the United States, elementary school teaching had by 1840 already become a preponderantly female occupation. In 1850, however, there were large regional differences. The mostly urban Northeast had $80 \%$ women, while the predominantly rural Midwest had the highest percentage of women at $82 \%$, which breaks with the pattern of all other cases in this chapter where female teachers are mostly dominant in urban areas. In the largely rural South, women comprised only 35\% of teachers (Rury, 1989, p. 17, Table 1.1). At a time when politics was heavily dominated by men, high percentages of women most likely did not contribute to the development of a tradition of rural leaders recruited from the group of schoolteachers, as seen in Norway and Denmark. Another, more general, explanation is that the strong control of education by local school boards in the United States placed teachers in a dependent position, especially in small towns and rural areas (Lauglo, 1995, p. 267). However, the large group of women in education contributed to the organisation and political mobilisation of women on a national level, e.g., during the struggles for women's suffrage in this period (Urban, 1989).

As also noted in the introduction to this chapter, American historiography thus shows the particular emancipatory significance that the occupation has had for some groups in the United States. Here, teachers as progressivist avant-garde fighters on behalf of oppressed groups and minorities, striving for power on a national level, played a central role for assertive and struggling groups. African American teachers confronting the realities of school segregation and the low quality of schooling for blacks, especially in the South, organised more and more during the 1880s and 1890s. By 1900, black teacher organisations existed in all southern states. The agenda of the National Association of Teachers in Colored Schools (NATCS), established in 1907, was that of promoting better educational opportunities, not least for the generations of new black leaders to come (Perkins, 1989).

\section{Swedish teachers: state-driven but late certification, early feminisation, urban-rural split}

There are a number of reasons for the comparatively late legislation on schooling and state-driven teacher education in Sweden, compared to Denmark and Norway. The system of home-schooling under the supervision of the church was long defended by the clergy, and school initiatives on the national level were stalled for reasons of funding during most of the first half of the nineteenth century (Westberg, Boser and Brühwiler, 2019). The first normal school and teacher seminary in Sweden was founded in 1830 by the Society for the Promotion of Monitorial Education (Sällskapet för växelundervisningens befrämjande) which was itself founded 
in 1822. In comparison with the Danish case, the introduction of the monitorial ${ }^{4}$ system in Sweden was not a top-down state-driven process but a civil society initiative, not unlike in the United Kingdom (Reeh and Larsen, 2014).

When the government did take control, however, a state-driven and centralised system emerged. Just after the Swedish School Act of 1842, which established mandatory schooling, 13 new seminaries for elementary schoolteachers for folk schools were founded in larger Swedish towns, all of them diocesan cities: Lund, Göteborg, Uppsala, Stockholm, Kalmar, etc. (Dahn, 1936). The folkskoleseminarier had a selfrecruitment rate of around 10\% from 1890, growing to around $20-25 \%$ in some cities like Uppsala and Göteborg by the turn of the century (Dahn, 1936, pp. 204f). Sweden thus had comparatively late certification at state seminaries, and low selfrecruitment rates.

Adding to this picture, however, was a state initiative to promote schooling in remote areas of the country. Under the 1853 law, these so-called 'small schools' (småskolor) were also opened up to female teachers. Although this was a state initiative, it was more locally organised and run than the elementary schools (folkskolor). During the 1860s and 1870s, a large number of seminaries for the education of small-school teachers opened, in both larger and smaller towns. Many of these seminaries, numbering almost a hundred, were stationary but others were ambulatory, and could provide as little as a few weeks of instruction. The ones located in the centre - in cities and important towns - had more systematic syllabuses and regular inspections (Florin, 1987, pp. 121f). The state tightened its control of the sector in 1870 and reformed the small-school seminaries into landstingsseminarier which were more centrally located, though not as much as the teacher seminaries for the folkskola.

Thus, professionalisation of the teaching profession in terms of a certified education occurred comparatively late in Sweden, compared to the German, Danish, and Norwegian cases. Moreover, teacher education was established as a quite centralised endeavour, although the urgent need for many small-school teachers to teach in local rural schools during the 1850s and 1860s was met through the more decentralised system of small-school seminaries.

From the start of the twentieth century, Swedish teacher education institutions were dominated by teacher educators with a relatively high level of academic training and a close affiliation to the universities. Holmén and Ringarp (Chapter 6) find that a very high academic level characterises teacher educators from this time on, and note that a reason for the higher share of teacher educators with a doctoral degree in Swedish seminaries might be that they were generally located in larger cities. It was thereby easier for them to recruit teachers with parallel careers in grammar schools or universities. Thus, we see a German pattern in the emulation of academically trained teachers even among elementary schoolteachers.

A special feature of the Swedish case, which is not to be found in any of the other Nordic countries, is that the small-school teachers were almost all female, and there was even a political decision that the new landstingsseminarier would be exclusively female. The small schools employed around 7,600 female teachers in 1910 and almost no male teachers (Florin, 1987, p. 41).

In recruitment to the higher-status folk-school seminaries, a swift squeezing out of lower-class rural women (allmogedöttrarna) can be observed. In 1907, 25\% of 
female student teachers at folk-school seminaries were of rural origin in Kalmar and Skara; in Umeå 17\%; and in Stockholm only 1\% (Dahn, 1936, p. 203). Dahn's national overview for $1922-1926$ shows that $60 \%$ of students during this time were male and $40 \%$ female. In the male group, less than $30 \%$ were farmers' sons, and in the female group, just under $20 \%$ were farmers' daughters. The opposite trend is evident for children of civil servants and professionals, who comprised $28 \%$ of the female group and $20 \%$ of the male group.

On the basis of these developments, the feminisation of the Swedish schoolteacher group can be seen to occur in two waves: a first wave with a rural lowerclass pattern, and a second wave with an urban pattern. This comparatively early feminisation, in some respects, resembles the American case. In spite of this recruitment pattern, the teaching occupation was a respected occupation in the Swedish case. The female teachers were not just 'social marionettes', they were the 'pioneers of civilisation', as Florin writes. Especially in the vast sparsely populated rural areas, in small villages, it was women who established Swedish people's education (folkbildning) (Florin, 1987, p. 14). A microhistory of Ester Vikström (b.1882), a smallschool teacher in the sawmill town of Furuögrund in north Västerbotten in Northern Sweden, shows a teacher who had aspirations to social mobility, rather than to be a spokesperson for the town's working-class population. Her social life was as a central character in the local community. In this social environment, she connected mostly with families of high social status, such as the pastor, the doctor, the inspector, and two sea-captains' families. But she found her husband-to-be, and a close friend, in a worker family (Marklund, 2017, p. 406).

A comparison of the Nordic countries opens up many questions about their differing teacher cultures. Differences are discussed in more detail elsewhere in this volume; e.g., Chapter 2 describes Swedish teacher culture as both more statist and more secular than the west-Nordic ones. From the above outline, it is clear that in Sweden, the placement of most seminaries in central cities, late professionalisation, and perhaps the comparatively early feminisation, may all be seen as underlying the absence of teachers playing a central role as leaders in countercultural rural movements that can be observed in both Denmark and Norway. Additionally, there is a large difference in the pace and organisation of female teacher education, which was private and more or less elitist in Denmark from its beginnings in the 1850s until the 1894 state legislation, while the female influx into the teaching profession in Sweden already from 1842 was a 'state public concern, a matter for the legislative power' and targeted a 'much broader social group' than in Denmark (Hilden, 1993, p. 49). As regards the more expansive national cultural self-understanding, the Swedish nationstate faced fewer challenges than either Denmark, which lost almost a third of its territory to Prussia in 1864, or Norway, which only gained full sovereignty in 1905.

\section{Finland and Iceland: colonising teachers in smaller and culturally defensive nation-states}

Finland, and perhaps Iceland, differ from the other Nordic countries as both culturally defensive nation-states and with colonising teacher types (see Figure 1.1). Whereas the Finnish case is arguably a clear example of this combination, as will 
be described below, Iceland is a bit ambiguous as it stands out due to its remarkable bottom-up tradition of lay teachers during most of the nineteenth century and a dominant rural recruitment. However, as urbanisation increased in the twentieth century, Reykjavík was for long, the dominant centre and the only site of teacher education in Iceland.

\section{Finland: the 'urban connection' of the teaching profession}

This volume contains several detailed accounts of the development of Finnish teacher education (see Chapters 5-7). This brief overview of the Finnish case shall therefore concentrate on the fact that urban elites kept their cultural hegemony, even with the slow turn from Swedish towards Finnish cultural dominance of the nation-state. This combination of a colonising teacher type with a defensive national self-understanding is explained by the fact that, in the threatened Finnish nation-state, the defining Finnish cultural awakening of the late nineteenth century was against foreign elites, not local urban ones. The cultural and linguistic differences between the Finnish majority and the elite Swedish-speaking minority were not directly connected to the survival of the Finnish nation during this period.Thus, the dominance of urban elites in defining Finland's self-understanding was less challenged than in Norway and Denmark. The area of education, from bottom to top, was dominated early - already under Russian rule - by efforts to secure the prime position of Finnish language and culture (Iisalo, 1979).

The central and prevailing tension between the towns and the countryside in Finland (Rinne, 1988, p. 106) can, however, be seen as parallel to the discussions in Norway and Denmark on having teachers coming from 'common' (rural) people teach the children of common people. The discussions in the Finnish journal The Teacher on admission to and length of teacher education programmes refer to a desire to recruit from 'common folk' around 1913. College entry based on primary school would ensure that the majority of teachers would themselves have risen from the common folk and from agrarian backgrounds, and would thus understand the background of the children they taught better (Jauhiainen, Kivirauma and Rinne, 1998).

But despite very late urbanisation (almost 90\% of the population lived in the countryside at the beginning of the twentieth century), the urban elites retained a hegemony on defining Finnish cultural and educational self-understanding. Popular teachers in the countryside had very low status - even at the turn of the century, they still did not have the right to vote, while their urban colleagues did - but were still perceived as representatives of an 'uncommon civilisation' in the rural communities (Rinne, 1988, p. 124). The urban connection of the teaching profession was also supported by the efforts of the teachers' union. Initiatives in the educational field tended to emanate from the urban centres towards the rural peripheries, but were only slowly adopted in these rural settings (Rinne, 1988).

Between 1880 and 1920, Finland experienced increasing oppression by the Russians and, finally, civil war. The Finnish case, therefore, is categorised in Figure 1.1 as a culturally defensive nation-state. The field of education was, however, characterised by a continuity of urban elite dominance, with a cultural agenda set by 
the Finnish nationalist movement, Fennoman. This resulted in teachers with a civilising role and a relatively high status - in the terms introduced above, a colonising teacher type.

\section{Iceland: from self-educated lay teachers to centrally educated professionals}

Due to its sparse population, in Iceland, ambulatory schooling was the rule throughout the eighteenth and nineteenth centuries, and made all the way into the middle of the twentieth century. The census of 1901 showed a population of around 80,000 people: around 6,600 lived in Reykjavík, and a handful of other towns had around 1,000 inhabitants each. Schools had very different enrolment rates in the central and peripheral parts of Iceland, from $90 \%$ in towns to $20 \%$ in the most remote counties in 1903-1904 (Garðarsdóttir, 2013, p. 143). The 1907 law on compulsory schooling did not change much in the short run. It did, however, raise the expected level of education for children, which slowly brought about a shift in educational arrangements in both urban and rural settings.

Teacher education was initiated very late. Short courses for teachers were provided in connection with the Flensborg secondary school in the town of Hafnarfjördur from 1892 and were extended to one-year courses in 1896. A law to establish a teacher training college was passed in Parliament in connection with the 1907 school law. In 1908, the Icelandic Teacher Training College was founded in Reykjavík and provided a three-year teacher training course, open to both men and women. Around 1900, we also find many examples of teachers who were educated abroad, most of them in Copenhagen (Garðarsdóttir, 2013, p. 149).

Before 1900, there were no data on recruitment into the teaching profession. The census of 1903-1904 gives some indications, with 35\% of the teaching staff being 'home-educated or self-educated' and another $24 \%$ having received some kind of vocational education (ibid.) In 1909-1910, there were 16 male and 20 female registered teachers in Reykjavík. Half of the female teachers belonged to higher-status families while two-thirds of the males were farmers' sons. Thus, the pattern of higher social status of the female teachers found in the other Nordic countries is repeated in Reykjavík (Garðarsdóttir, 2019, p.210,Table 2; Garðarsdóttir and Guttormsson, 2014, fn. 10). In the countryside, in 1909-1910, teachers primarily were male (85\%) and came from farming families (72\%). The father's occupation is unknown in many cases $(15 \%)$. Only a few of the teachers in the countryside came from teacher backgrounds (less than 4\%).

By around 1930, the number of teachers in Reykjavík tripled to 100, of whom 56 were men and 44 women (Garðarsdóttir, 2019, p. 210, Table 2). A large number of the female teachers in this group, 39\%, were from farming backgrounds. The next largest group comprised daughters of academics or officials (25\%), followed by daughters of teachers (16\%). Among the male teachers in Reykjavík, as many as $75 \%$ were sons of farmers, and some were sons of teachers (7\%), and craftsmen (7\%). There was thus substantial recruitment of teachers from the countryside into Reykjavík. Outside the capital, by around 1930, the number of teachers had risen to 785 (72\% male, $28 \%$ female). While $78 \%$ of all male teachers were farmers' sons, $73 \%$ of all female teachers were from farming families (Ibid., Table 2). 


\section{Jesper Eckhardt Larsen}

These numbers show high and persistent recruitment from farming families, with an increase between 1909-1910 and 1930-1931. In the 1930s, these percentages were higher in Iceland than in Norway and Denmark. However, these data have not been weighted with respect to the occupational demographics of the general population.

The case of Iceland does not show any indications of a cultural split between an urban academic elite and countercultural teacher education institutions. This may be due to the late establishment of both compulsory schooling and teacher education. When these finally came about, in the early twentieth century, Reykjavík became the natural centre for both teacher education (1908) and academic education at the University of Iceland, founded in 1911. Later, during the development of the welfare state, the former Teacher Training College was academised and transformed into a university college in 1971. We can thus observe a parallel to the Finnish development of early integration between teacher education and the universities.

Iceland's prolonged dependence on Denmark resulted in a culturally defensive nation (see Figure 1.1), giving, for instance, high priority to the development of the national language. Yet, the connection to Denmark remained culturally important, and as noted above, many teachers completed their education in Copenhagen. Iceland's school legislation was quite autonomous, although the country did not become a fully independent republic until 1944. The Icelandic schoolteacher was hardly a stranger to rural communities, as the predominantly rural recruitment pattern shows. However, after 1908, all teachers were educated in Reykjavík or abroad, which may be tentatively taken to have resulted in teachers of the colonising type.

\section{Discussion: co-occurrences and causes}

As noted in the introduction, the framework presented in Figure 1.1 shows no direct causal connections between the type of nation-state and the type of teacher, but serves as an overview of co-occurrences. Thus, premature conclusions that expansive $<=>$ colonising, or defensive $<=>$ organic are to be avoided. With two 'outliers', Finland and Iceland, this hypothesis had to be questioned. Therefore, in this brief discussion of the cases, some alternative explanations need to be investigated.

These outliers demonstrate that the colonising teacher type does not only cooccur with culturally expansive strategies, but also in the case of Finland and, less strongly in Iceland, we see a co-occurrence between a defensive cultural strategy and a colonising teacher type.

In these cases, an alternative explanation relates to the urban bourgeois dominance in the national cultural self-understanding. This could explain the Finnish case and also the ambiguity we find in the German case between the initial national awakening (ca. 1800) and the later unification (1871 onwards).

In Finland, the combination of a colonising teacher type with a defensive national self-understanding is explained by the fact that, in a nation-state under first Swedish, then Russian control, the defining cultural awakening of the late nineteenth century was against foreign elites, not local urban ones. The Fennoman movement didn't cater to either Swedish or Russian foreign dominance. By this 
time, the cultural and linguistic differences between the Finnish majority and the elite Swedish-speaking minority were not directly connected to the survival of the Finnish nation. Meanwhile, already under Russian rule, the area of education, from bottom to top, was dominated by efforts to secure the prime position of Finnish language and culture. Here, therefore, the dominance of urban elites in defining Finland's self-understanding was less challenged than in the two Nordic countries that also demonstrate a culturally defensive strategy: Denmark and Norway. In Norway, the Danish language and culture were continuously celebrated by urban groups (the Dannomane), which reinforced the anti-urban nature of the countercultural movement. In Denmark, after its defeat to Prussia in the 1864 war and the loss of its German-speaking territories, the nation-state redefined itself along ethnic lines, and this new national self-understanding increasingly came to be defined by Grundtvigian countercultural movements of rural origin, and anti-German sentiments.

The ambiguity of the German case lies in the cultural strategy of the nation, not in the teacher type. As noted earlier, German national identity formed in a defensive bourgeois showdown that set German Kultur against French civilisation. But the reaction was not to turn to rural national culture as it happened in Denmark in late nineteenth century; instead, the German urban bourgeoisie formed the centre of national self-understanding, characterised by a lateral relationship between the educated middle classes in German cities. However, in spite of this originally defensive self-understanding Germany also shows traits of an expansive cultural strategy, not least after unification occurred in 1871. Therefore, the German case is not unlike the Finnish one, with traits of cultural defensiveness combined with an urban dominance of the educational sphere.

But if urban dominance is the key to a colonising teacher type, how does this fit with other cases that also demonstrate a colonising teacher type? Sweden, Iceland, and the United States differ in the ways they sought a sort of compromise between urban elites and rural interests. Sweden and Iceland share the positive connotations of the Nordic folk ideology which implies a certain class compromise and, by extension, a geographical compromise. The United States after the Civil War was also arguably built on a geographical compromise between urban elites and rural stakeholders. A common trait is that these nations did not have countercultural movements establishing their 'own' institutions of pre-service teacher education. In these cases, therefore, the educational spheres were not culturally divided as in Norway and Denmark.

Another indicator of the emergence of an organic teacher type is a rural countercultural movement that was strong and enduring enough to establish teacher education institutions of its own. In Denmark and Norway, the countercultural movements were strong enough that civil society actors were able to establish preservice teacher education institutions. Yet, even this is not a necessary prerequisite. A case not outlined here, that of Switzerland, also shows traces of an organic teacher type which emerged without a strong, organised countercultural movement (Bascio, 2018). And Ireland's relatively late independence created a political consensus on the (new) national level creating such a teacher type from above rather than through a countercultural movement. 
Thus, the variables of national cultural strategy, urban bourgeois dominance, class-compromising ideologies, and countercultural movements do not sum up cleanly to clear and linear lines of causal inference. Rather, different paths lead to the emergence of both the organic and the colonising teacher types.

\section{Conclusion}

Teachers in the late nineteenth and early twentieth centuries were a nonhomogeneous group, characterised by a certain social plasticity. Sometimes they were socially mobile, with ambitions of climbing the social ladder into the educated middle classes. In other instances, they comprised a group with strong anti-elite sensibilities, advocates, and ambassadors for the 'people' as primus inter pares among assertive new groups such as Danish farmers, or they were carriers of emancipatory agendas, aiming to gain empowerment and positions on a national level - not least female teachers in the Nordic countries, who promoted women's rights on a national level.

The construction of the folk teacher was, in Norway and Denmark, built on a segmented institutional landscape, with special, often rural, institutions established for teacher education. These institutions became carriers of a civil society counterculture, which slowly gained a nationally dominant status, not least through the agency of teachers as organic intellectuals, emerging from the soil. Arguably, the colonising teacher type was equally important for the national self-understanding of Sweden as a modern, emancipatory power. Iceland, and especially Finland, which are more culturally defensive nation-states, also had traits of a colonising teacher type, which was largely uncontested on a national level.

Teacher lives were often socially divided, with backgrounds in manual labour families, and a working practice of more intellectual labour. Most of these teachers grew up in 'practical' homes and were the first intellectuals in their families. This may be the root of the 'practicism' found in American progressivism of the time, as well as in the Grundtvigian critique of 'dead learning' in Denmark. A risk, especially of the organic teacher type, is therefore that this potential anti-intellectualism becomes a celebrated trait of the profession. This tendency can, at least partly, explain the still active opposition to academisation in Danish pre-service teacher education (Larsen, 2016).

What, then, is the significance of distinguishing between 'organic' and 'colonising' teacher types? As the title of this chapter indicates, both teacher types can be viewed as important vehicles of national mobilisation, in Elias's sense of building the cultural as well as the political survival capacity for the nation-state. In both types, the centre sends out educators to promote loyalty to the nation-state in all its geographical parts. The key difference is that, in the case of the colonising type, the centre's own culture defines the values of its civilising efforts, while where organic teacher types prevail, the ruling elites ally with peripheral, and maybe primordial, cultures to promote nationally cohesive values.

This raises questions as to the real role of schoolteachers more generally, if we consider the nation-state as a survival unit, to use Elias's term. It seems as if the aims of national mobilisation are the same, but the means may differ. The mobilisation of primordial folk culture into national self-understanding via the agency of an organic teacher type may, in effect, be equal to the Protestant Reformation, 
which brought about a Christianising 'in depth' (see Chapter 2). In Norway, the alliance between the urban elites and the new popular elites, i.e., the folk teachers, led to a group of teachers with unquestioned loyalty to the nation. The Nordic cases all show a high level of societal trust and trust in their state apparatus (Wollebæk et al., 2012). And teachers, who are emissaries of the state but mediate with civil society - and who meet the people on an equal standing as folk teachers - can perhaps preserve a nationalism and state loyalty that is less often seen with purely colonising teacher types.

The opposite argument can, however, also be made. In defining which ideologies to disseminate, teachers, regardless of type are 'not just social marionettes' (Florin, 1987). An intimate connection exists between the self-understanding they share as groups, and what they in fact disseminate to pupils and parents. This relates to how the teaching occupation has been an opening for upcoming leaders of struggling, yet assertive, groups. It may be argued that what we observe in the late nineteenth century is a mobilisation of struggling groups which lacked the rights or the means to pursue elite education and career trajectories. Ambitious women, African Americans, and Danish farmers were thus forced - or inclined - first to go back to school as teachers, and then, as a second step, use this vocation as a platform for their assertive struggles for equal opportunities, empowerment, positions, and rights on the national level.

\section{Notes}

1 The overview by C. Larsen shows 1,434 women and 4,597 men were educated at seminaries for elementary schoolteachers during 1866-1889, i.e., $24 \%$ women and $76 \%$ men (Larsen, 2005). These figures are not comparable, as Copenhagen is not included in the 1895 statistical overview, which shows 612 female teachers (15\%) and 3,379 (85\%) male teachers outside Copenhagen (Tabellariske Meddelelser vedrorende Borger- og Almueskolevasenet udenfor Kjøbenhavn for Aaret 1895, 1899). The 720 female teachers mentioned in the text are from a contemporary source (N. Tuxen 1890 quoted in Hansen, 1977, p. 37).

2 The percentage of offspring of 'merchants including workers' is the sum of two of Bölling's categories: Handwerker, Kaufleute, Gastwirte usw. plus Arbeiter. The percentage noted under 'higher and lower officials' as well as other 'white-collar workers' is a sum of three categories: Untere Beamten, Mittlere Beamten, and Angestellte. The reason for these summations is that Bölling is more interested in status groups or social positions in the recruitment patterns than in specific occupations or rural/urban distinctions (Bölling, 1983, pp. 76ff).

3 Here, there are similar problems of categorisation as in endnote 2 above, as Bölling listed data according to social stratification, not rural/urban distinctions.

4 The 'monitorial' or 'Lancaster' system of instruction was a structured and systematised approach in which pupils mutually taught each other. It was introduced in Denmark around 1814 and later in other Nordic countries, imported from the United Kingdom (Caruso, 2010; Reeh and Larsen, 2014).

\section{References}

Albisetti,J.C. (1993) 'The feminization of teaching in the nineteenth century:A comparative perspective', History of Education, 22(3), pp. 253-263.

Bascio, T. (2018) 'Metaphors of naturalness in the context of Swiss teacher education 1975-1985,' International Standing Committee for the History of Education, ISCHE 40, Berlin, 29 August to 1 September 2018. 
Bölling, R. (1978) Volksschullehrer und Politik. Die Deutsche Lehrerverein 1918-1933, vol. 32. Göttingen:Vandenhoeck \& Ruprecht.

Bölling, R. (1983) Sozialgeschichte der deutschen Lehrer. Ein Überblick von 1800 bis zur Gegenwart. Göttingen:Vandenhoeck \& Ruprecht.

Buck, P.H., Finley, J.H., Demos, R., Hoadley, L., Hollinshead, B.S., Jordan, W.K., Richards, I.A., Rulon, P.J., Schlesinger, A.M., Ulich, R., Wald, G. and Wright, B.F. (1945) General education in a free society. Report of the Harvard Committee. Cambridge, MA: Harvard University Press.

Caruso, M. (2010) Geist oder Mechanik. Unterrichtsordnungen als kulturelle Konstruktionen in Preussen, Dänemark (Schleswig-Holstein) und Spanien 1800-1870, vol. 19. Frankfurt am Main: Peter Lang.

Caruso, M. (2012) 'Politics and educational historiography: Criticizing "civilization" and shaping educational politics in Latin America', in Larsen, J.E. (ed.), Knowledge, politics and the history of education. Berlin: Litt-Verlag, pp. 151-175.

Coffman, L.D. (1911) The social composition of the teaching population. New York: Columbia University.

Dahn, P. (1936) Studier rörande den studerande ungdomens geografiska och sociala härkomst. Lund: C.W.K. Gleerup.

Dokka, H.-J. (1967) Fra allmueskole til folkeskole. Studier i den norske folkeskoles historie i det 19. århundrede. Bergen: Universitetsforlaget.

Elias, N. (1978) What is sociology? Mennell, S. and Morrissey, G. (trans.). London: Hutchinson of London.

Elias, N. (1995) Über den Prozess der Zivilisation. Soziogenetische und psychogenetische Untersuchungen, vol. 1. Frankfurt am Main: Suhrkamp Taschenbuch Verlag.

Enzelberger, S. (2001) Sozialgeschichte des Lehrerberufs. Gesellschaftliche Stellung und Professionalisierung von Lehrerinnen und Lehrern von den Anfüngen bis zur Gegenwart. Weinheim and München: Juventa Verlag.

Fischer, R. (1916) Beiträge zu einer Statistik der deutschen Lehrerschaft. Ergebnisse der von der Statistischen Zentralstelle des Deutschen Lehrervereins am 1. April 1913 veranstalteten Erhebung. Leipzig: Schriften der Statistischen Zentralstelle des Deutschen Lehrervereins. H.4.

Florin, C. (1987) Kampen om Katedern. Feminiserings- och professionaliseringsprocessen inom den svenska folkskolans lärarkår 1860-1906. Umeå: Umeå universitet.

Garðarsdóttir, Ó. (2013) 'Teaching on the eve of public schooling: Demographic and social features of Icelandic schoolteachers in the beginning of the 20th century', in Buchardt, M., Markkola, P. and Valtonen, H. (eds.), Education, state and citizenship. Helsinki: Nordic Centre of Excellence Nordwell, pp. 138-159.

Garðarsdóttir, Ó. (febrúar, 2019) 'Kennslukonur í Barnaskóla Reykjavíkur í upphafi 20. aldar', in Jónsson, G. (ed.), Nýtt Helgakver. Rit til heiðurs Helga Skúla Kjartanssyni sjötugum 1. Reykjavík: Sögufélag, pp. 201-220.

Garðarsdóttir, Ó. and Guttormsson, L. (2014) 'Changes in schooling arrangements and in the demographic and social profile of teachers in Iceland, 1930-1960', Nordic Journal of Educational History, 1(1), 7-20. doi: 10.36368/njedh.v1i1.31.

Göttlicher,W.G. (2019) Die österreichische Landschulreform von den 1920er-bis zu den 1960erJahren. Untersuchung einer vergangenen Schulreformdebatte.Vienna: Universität Wien.

Gramsci, A. and Hoare, Q. (1971) Selections from the prison notebooks. London: Lawrence and Wishart.

Grinder-Hansen, K. (2013) Den gode, den onde og den engagerede. 1000 år med den danske larer. Copenhagen: Mussmann' forlag.

Grundtvig, N.F.S. (2016 [1816]) 'Danne-Virke', in Grundtvigs Verker. Aarhus: Aarhus University Press. 
Hagemann, G. (1992) Skolefolk: laerernes historie i Norge. Oslo: Ad notam Gyldendal.

Hansen, V.H. (1977) Lacernes sociale rekruttering 1869-1925. En undersegelse af fire statsseminariers dimittender 1869-96 samt en oversigt over det samlede antal dimittender 1897-1925. Copenhagen: Københavns Universitet.

Hilden, A. (1993) 'Lærerindeuddannelse 1800-1950', in Skovgaard-Petersen, V. (ed.), Dansk laceruddannelse 1791-1991, vol. 3. Odense: Syddansk Universitetsforlag, pp. 19-303.

Hjermitslev, H.H. (2020) 'Grundtvigske seminarier 1840-1920', Uddannelseshistorie, 54, pp. 63-96.

Høydal, R. (1995) Periferiens nasjonsbyggjarar. Vestlandslararen og Volda lacrarskule 1895-1920, vol. 39. Oslo: Noregs forskingsråd.

Iisalo, T. (1979) The science of education in Finland, 1828-1918. Helsinki: Societas Scientiarum Fennica.

Jauhiainen, A., Kivirauma, J. and Rinne, R. (1998) 'Status and prestige through faith in education:The successful struggle of Finnish primary schoolteachers for universal university training', Journal of Education for Teaching, 24(3), pp. 261-272.

Johnson, N.C. (1992) 'Nation-building, language and education: The geography of teacher recruitment in Ireland, 1925-55', Political Geography, 11(2), pp. 170-189.

Jordheim, K. (1988). 'Læreren i norsk samfunns- og kulturliv. En oversikt for det 20. århundred', in Rinne, R. and Iisalo, T. (eds.), Läraren i 1900-tallets kultur och samhälle. Åbo:Turin yliopisto, pp. 67-93.

Larsen, C. (2005) 'Dimmittender 1793-2002', in Skovgaard-Petersen,V. (ed.), Dansk lareruddannelse 1791-1991, vol. 1. Odense: Syddansk Universitetsforlag, pp. 422-427.

Larsen, J.E. (2016) 'Academisation of teacher education: Sites, knowledge cultures and changing premises for educational knowledge in Norway and Denmark', in HoffmannOcon, A. and Horlacher, R. (eds.), Pädagogik und pädagogisches Wissen: Ambitionen und Erwartungen an die Ausbildung von Lehrpersonen. Pedagogy and Educational Knowledge: Ambitions and Imaginations in Teacher Education. Bad Heilbrun:Verlag Julius Klinkhardt, pp. 211-228.

Lauglo, J. (1982) 'Rural primary schoolteachers as potential community leaders? Contrasting historical cases in Western countries', Comparative Education, 18(3), pp. 233-255.

Lauglo, J. (1995) 'Populism and education in Norway', Comparative Education Review, 39(3), pp. 255-279.

Marklund, E. (2017) 'Ett år med Ester: En mikrohistorisk undersökning av det sociala nätverket och känslolivet hos en småskollärare vid sekelskiftet 1900', Historisk Tidskrift (S), 137(3), pp. 379-410.

Perkins, L.M. (1989) 'The history of blacks in teaching: Growth and decline within the profession', in Warren, D. (ed.), American teachers: Histories of a profession at work. New York: Macmillan Publishing Company, pp. 344-369.

Reeh, N. (2016) Secularization revisited-teaching of religion and the state of Denmark: 1721-2006, vol. 5. Switzerland: Springer International.

Reeh, N. and Larsen, J.E. (2014) 'From competing technologies of mass schooling to the spiritual enlightenment of the nation: The reception of the monitorial system of education in Denmark 1814-1849', in Caruso, M. (ed.), Classroom struggle: Organizing elementary school teaching in the 19th century. Frankfurt am Main: Peter Lang.

Rinne, R. (1988) 'The formation and professionalization of the popular teachers in Finland in the 20th century', in Iisalo, T. and Rinne, R. (eds.), Lärarren i 1900-tallets kultur og samhälle. Nordisk utbildningshistorisk forskarträff $i$ Åbe den 18-19 augusti 1987. Turun/Åbo, pp. 106-148.

Rury, J.L. (1989) 'Who became teachers? The social characteristics of teachers in American history', in Warren, D. (ed.), American teachers: Histories of a profession at work. New York, London: Macmillan, pp. 9-48. 
Schulte, B. (2014) 'Grenzen im Inneren: Die pädagogische Missionen chinesischer Rückkehrer im Hinterland zu Beginn des 20. Jahrhunderts', in Caruso, M., Koinzer, T., Mayer, C. and Priem, K. (eds.), Zirkulation und Transformation. Pädagogische Grenzüberschreitungen in historischer Perspektive. Wien, Köln, Weimar: Böhlau, pp. 211-230.

Slagstad, R. (1998) De nasjonale strateger. Oslo: Pax.

Slagstad, R. (2008) 'Profesjoner og kunnskapsregimer', in Molander, A. and Terum, L.I. (eds.), Profesjonsstudier. Oslo: Universitetsforlaget, pp. 54-70.

Strømnes, Å.L. (2006) Folkeskulelararar i Fattig-Noreg. Ein studie frå forste halvdel av det tjuande hundreåret. Trondheim: Tapir Akademisk Forlag.

Tabellariske Meddelelser vedrørende Borger- og Almueskolevesenet udenfor Kjøbenhavn for Aaret 1895. (1899) Copenhagen: Ministeriet for Kirke- og Undervisningsvæesenet.

Trägårdh, L. (1990) 'Varieties of völkish ideologies. Sweden and Germany 1848-1933', in Stråht, B. (ed.), Language and the construction of class identities. The struggle for discursive power in social organisation: Scandinavia and Germany after 1800, Report from the DISCO II Conference, Gothenberg: Göteborg University.

Urban, W.J. (1989) 'Teacher activism', in Warren, D. (ed.), American teachers. Histories of a profession at work. New York: Macmillan Publishing Company, pp. 190-209.

Westberg, J., Boser, L. and Brühwiler, I. (2019) School acts and the rise of mass schooling: Education policy in the long nineteenth century. Switzerland: Palgrave Macmillan.

Wiborg, S. (2009) Education and social integration: Comprehensive schooling in Europe. New York: Palgrave Macmillan.

Wollebæk, D., Enjolras, B., Steen-Johnsen, K. and Ødegård, G. (2012) 'After Utøya: How a high-trust society reacts to terror-trust and civic engagement in the aftermath of July 22', PS: Political Science and Politics, pp. 32-37. doi: 10.1017/S1049096511001806. 